\title{
Microwave Irradiation Assisted Supercritical Carbon Dioxide Extraction of Bio-Oils from Chlorella Vulgaris Microalgae
}

\author{
S.N. Ibrahim ${ }^{1}$, K.A. Radzun ${ }^{1 *}$, K. Ismail ${ }^{1,2}$ \\ ${ }^{\text {I}}$ Faculty Applied Sciences, Universiti Teknologi MARA (UiTM), 40450, Shah Alam, Selangor, Malaysia, \\ ${ }^{2}$ Coal and Biomass Energy Research Group, Universiti Teknologi MARA (UiTM), 40450, Shah Alam, Selangor, Malaysia \\ *Corresponding author E-mail: khairuladzfa@salam.uitm.edu.my
}

\begin{abstract}
Chlorella vulgaris is one of the promising microalgae strains that can produce high yield of bio-oils. The C. vulgaris was pretreated with microwave irradiation prior to extraction using supercritical carbon dioxide $\left(\mathrm{SCCO}_{2}\right)$. Fourier transform infrared spectroscopy (FTIR) analysis showed microwave irradiation pretreatment does not affect the material composition of $C$. vulgaris. Scanning electron microscopy (SEM) of the microwave irradiation pretreated microalgae showed an agglomeration of the cells with the cells shape became distorted due to rupturing of the cell walls. Optimization of the $\mathrm{SCCO}_{2}$ process parameters (pressure, temperature and $\mathrm{CO}_{2}$ flow rate) was performed by using response surface methodology (RSM) with central composite design (CCD). Two factors significantly affecting the extraction yield were temperature and pressure. The model equation also predicted the optimum condition for the $\mathrm{SCCO}_{2}$ (without microwave pretreatment) at $70^{\circ} \mathrm{C}, 5676 \mathrm{psi}$ and $7 \mathrm{sL} / \mathrm{min}$ while optimum condition for $\mathrm{SCCO}_{2}$ (microwave irradiation pretreatment) at $63^{\circ} \mathrm{C}$, $5948 \mathrm{psi}$ and $10 \mathrm{sL} / \mathrm{min}$. High amount of saturated fatty acids (SFA), monounsaturated fatty acids (MUFA), $\alpha$-linolenic acid and palmitoleic acid were found in the extracted oil with microwave irradiation pre-treatment sample. In addition, the polyunsaturated fatty acids (PUFA) content in the microwave irradiation pretreated oil was considerably low and is desirable for biodiesel production.
\end{abstract}

Keywords: Response surface methodology; supercritical carbon dioxide extraction; pretreatment; Chlorella vulgaris; Microwave irradiation; fatty acid methyl ester.

\section{Introduction}

Biodiesel is defined as alkyl monoesters of long-chain fatty acids derived from triglycerides which have been used in transportation [1]. Recently, microalgae have shown to be among the most promising non-food-crop-based biomass feedstocks for biodiesel production. Furthermore, microalgae are easy to grow as it can be grown away from farm land and forests such as in pond and wastewater [2]. Extraction of bio-oil from microalgae however, imposed several challenges due to the toughness of their cell walls that may reduce the efficiency of the extraction process. Hence, some pretreatment are necessary to be applied to the microalgae prior to extraction process. Mcmillan and co-workers had made comparison on the effectiveness of several pre-treatment methods such as microwave irradiation, water bath, ultrasonic blender and laser in an attempt to break and disrupt the cell walls. The results showed that microwave irradiation was the most effective method that able to disrupt the cell walls while ultrasonic method was the least effective [3]. In another study, autoclaving, bead-beating, microwave irradiation and ultrasonication in $10 \% \mathrm{NaCl}$ solution were used on microalgae as pretreatment method prior to extraction process using a mixture of chloroform and methanol. The results revealed that the microwave irridiation method was found to be the simplest and effective method for the cell walls disruption [4].

Supercritical carbon dioxide extraction $\left(\mathrm{SCCO}_{2}\right)$ is recommended for lipid extraction because it is the most efficient and more environmental friendly procedure. Further, $\mathrm{SCCO}_{2}$ has been used widely because this extraction method has proven that it is of green technology and easy in comparison to the conventional solvent extraction [5]. In addition, the use of $\mathrm{CO}_{2}$ as solvent have given many advantages such as non-toxic, inexpensive and abundantly available [6]. Recently, Cheng et.al [7] have made comparison studies between conventional solvent extraction and $\mathrm{SCCO}_{2}$ and found that the latter was proven to be more effective and provide higher selectivity for triglycerides extraction. Several researches have reported the application of $\mathrm{SCCO}_{2}$ to extract lipids and bioactive compounds from plants such as pomegranate, wheat germ, banana peel and mango [7]-[10] .

In this study, bio-oil was extracted from $C$. vulgaris microalgae using $\mathrm{SCCO}_{2}$. This strain was identified as one of the microalgae species that has significant amount of lipids [11]. The bio-oil extracted from the microwave irradiation pretreated microalgae using $\mathrm{SCCO}_{2}$ was analysed and comparison was made with the untreated microalgae in terms of extraction yield and composition of fatty acids content. The optimization on extraction process parameters (i.e. temperature, pressure and $\mathrm{CO}_{2}$ flow rate) of microalgae using $\mathrm{SCCO}_{2}$ with and without microwave irradiation pretreatment was conducted using response surface methodology (RSM) with CCD model and the results were discussed accordingly. 


\section{Materials and Methods}

\subsection{Microalgae and chemicals}

Dried biomass of microalgae, C. vulgaris was obtained from $\mathrm{Al}-$ gaetech International company (Malaysia). The dried biomass was kept in silica gel to avoid the absorption of moisture. Absolute ethanol (99.9\%) was used for cleaning purposes after running the $\mathrm{SCCO}_{2}$. Pure $\mathrm{CO}_{2}$ gas (99.9\% purity) was purchased from PolyGas Sdn. Bhd. (Selangor, Malaysia).

\subsection{Instrumental analysis}

The biochemical composition of $C$. vulgaris microalgae before and after pre-treatment was determined from traditional techniques. The protein analysis was carried out using lowry method [12] and the carbohydrate analysis was carried out using phenol sulfuric acid method [13]. Lipid extraction was done using soxhlet extraction using hexane as the solvent. The elemental compositions of carbon $(\mathrm{C})$, hydrogen $(\mathrm{H})$, nitrogen $(\mathrm{N})$ and sulphur $(\mathrm{S})$ in C. vulgaris from untreated and pretreated samples were analysed using CHNS analyser (Flash 2000, Thermo scientific) with oxygen $(\mathrm{O})$ was estimated by the difference $(\mathrm{O} \%=100 \%-\mathrm{C} \%-\mathrm{H} \%$ - N\% - S\%) [14].

\section{3 $\mathrm{SCCO}_{2}$ extraction}

The extraction of bio-oil was done using supercritical carbon dioxide extraction $\left(\mathrm{SCCO}_{2}\right)$ unit (TST, Ltd., Taiwan). The collection vial was pre-weighed prior to extraction. Then, $15 \mathrm{~g}$ of dried biomass was weighed and packed inside $60 \mathrm{~mL}$ extraction vessel and placed inside an oven designated for the extraction. After the oven reached the desired temperature, $\mathrm{CO}_{2}$ was passed, delivered and compressed into the vessel by an air compressor. Then, the pump was started and $\mathrm{CO}_{2}$ was pumped and discharged into the vessel from an incoming valve at the bottom and went out through the outcoming valve at the upper part of the vessel. The extraction was done in static mode for $10 \mathrm{~min}$, then in dynamic mode for 10 min with the flow rate in range 6 to $10 \mathrm{sL} / \mathrm{min}$. The static and dynamic mode cycle was continued for 3 hours. The experiment was carried out in a wide range of temperature and pressure as listed in Table 2.1. The crude bio-oil was collected in collection vial and the extraction yield was calculated according to equation 1:-

$\%$ Extraction yield $=\frac{\text { Mass of crude oil }}{\text { Mass of dried biomass }} \times 100$

\subsection{Microwave irradiation pre-treatment of dried mi- croalgae}

The microwave irradiation pretreatment of dried C. vulgaris biomass was carried out according to procedure published earlier [16] The pre-treatment process was done using the commercial microwave oven (me711k, Samsung) equipped with variable output microwave power up to $800 \mathrm{~W}$ at the frequency of $2450 \mathrm{MHz}$. Initially, $15 \mathrm{~g}$ of dried C. vulgaris was weighed and placed into a pyrex beaker inside a microwave oven. The dried biomass was irradiated at $700 \mathrm{~W}$ for $3 \mathrm{~min}$.

\subsection{Experimental design for $\mathrm{SCCO}_{2}$ extraction}

In this experiment, three independent variables i.e. pressure, reaction temperature and $\mathrm{CO}_{2}$ flow rate were used to observe the effect on dependent variable i.e. percent of extraction yield. These three independent variables were optimized using response surface methodology (RSM). Central composite design (CCD) in response surface methodology was employed using Design Expert Version 6.0.4 (StatEase, USA). CCD was employed in this study for the prediction and verification of the model equation (i.e. Equation 3) and also for the optimization of the dependent response as the function of the independent response [17].

Table 1: Factors and Levels Tested in Designed Experiment for SFE

\begin{tabular}{lcccccc}
\hline \multicolumn{1}{c}{ Variables } & Symbols & \multicolumn{5}{c}{ Level } \\
\hline & & $\begin{array}{c}1.682 \\
-\alpha\end{array}$ & -1 & 0 & +1 & $\begin{array}{c}1.682 \\
+\alpha\end{array}$ \\
$\begin{array}{l}\text { temperature, } \\
{ }^{\circ} \mathrm{C}\end{array}$ & $\mathrm{A}$ & 30 & 40 & 55 & 70 & 80 \\
$\begin{array}{l}\mathrm{P} \text { ressure, } \\
\text { psi }\end{array}$ & $\mathrm{B}$ & 1977 & 3000 & 4500 & 6000 & 7023 \\
$\begin{array}{l}\mathrm{CO}_{2} \text { flow } \\
\text { rate, sL/min }\end{array}$ & $\mathrm{C}$ & 5 & 6 & 8 & 10 & 11 \\
\hline
\end{tabular}

Three factors were explored during the optimization. Each factor was varied in five levels which are high $(+1)$, low $(-1)$, the centre point (0) and two outer points corresponding to value of 1.6818 as in Table 1 [18]. The RSM was used to determine the optimum conditions of the inputs which produces the most output and to determine empirical models which allow predictions of process performance in some region of the optimization [17]. In order to obtain the required data, 20 runs of experiment were needed including eight factorial points, six axial points and 6 replicated centre points as derived in equation 2 . Replicates at the centre point were very important as they provide an independent estimate of the experimental error

$$
\mathrm{Y}=2 \mathrm{~K}+2 \mathrm{~K}+\mathrm{m}
$$

Where,

$Y=$ the percentage of extraction yield
$K=$ Number of factors

$m=$ number of replicated centre points

Before designing the experiment, the variables of supercritical $\mathrm{CO}_{2}$ were determined based on previous reports [5], [15]. The CCD model was chosen because it can provide as much information as a three level factorials, which required fewer test than the full factorial design and has been shown to be more sufficient to describe the majority of steady-state process responses [19].

\subsection{Fatty acid methyl ester analysis (FAME)}

The crude bio-oil of $C$. vulgariswas converted into fatty acid methyl ester (FAME) by transesterification process. This transesterification method was adopted from [20]. $400 \mathrm{mg}$ of crude bio-oil was weighed and $4 \mathrm{~mL}$ of boron trifluoride in methanol was added for the transesterification process at $80^{\circ} \mathrm{C}$ for 2 hours in the oven. After the reaction has completed, $4 \mathrm{~mL}$ of chloroform and deionized water were added to the mixture. Then, the mixture was centrifuged. After the centrifugation, the bottom layer was collected and the upper layer was discarded. The product from the bottom layer was used for analysis using gas chromatography with mass spectrometer (GCMS).

FAME was analysed using GCMS (6890N Agilent) with HP5-MS column. Purified helium (99.9995\%) was used as a carrier gas. The sample was injected at an initial temperature of $50^{\circ} \mathrm{C}$. Then, the oven was heated at $10^{\circ} \mathrm{C} \mathrm{min}^{-1}$ to $170^{\circ} \mathrm{C}$, at $5^{\circ} \mathrm{Cmin}^{-1}$ to $210^{\circ} \mathrm{C}$ and was held for $10 \mathrm{~min}$. The temperature was continuously increased to $230^{\circ} \mathrm{C}$ at $5^{\circ} \mathrm{Cmin}^{-1}$ and was held for $6 \mathrm{~min}$. The injector and detector were set at $260^{\circ} \mathrm{C}$. The fatty acids were identified by referring to the library's mass spectral database. 


\section{Results and discussion}

\subsection{Biochemical and elemental analysis}

Carbohydrates, proteins and lipids contents in C. Vulgaris with and without microwave irradiation pre-treatment were analysed and comparison were made in this study. With reference to Table 2, carbohydrates composition in untreated $C$. Vulgaris was comparable to the microwave treated sample. However, both proteins and lipids in microwave irradiation pre-treated sample were slightly higher in comparison to the untreated sample.

Table 2: Biochemical and elemental compositions

\begin{tabular}{lll}
\hline Chlorella vulgaris & Untreated sample & $\begin{array}{l}\text { Microwave irradiation pre- } \\
\text { treated sample }\end{array}$ \\
\hline Carbohydrates & $0.68 \mathrm{mg} / \mathrm{ml}$ & $0.69 \mathrm{mg} / \mathrm{ml}$ \\
Proteins & $0.77 \mathrm{mg} / \mathrm{ml}$ & $0.82 \mathrm{mg} / \mathrm{ml}$ \\
Lipids & $9.90 \%$ & $10.15 \%$ \\
Elemental analysis $(\%)$ & \\
$\mathrm{C}$ & 41.68 & 46.87 \\
$\mathrm{H}$ & 6.96 & 7.45 \\
$\mathrm{~N}$ & 3.76 & 4.25 \\
$\mathrm{~S}$ & 0.00 & 0.00 \\
$\mathrm{O} *$ & 47.79 & 41.42 \\
\hline$*$ estimated by difference &
\end{tabular}

Apparently, the $\mathrm{C}, \mathrm{H}$, and $\mathrm{N}$ elemental contents in microwave irradiation pre-treated sample were higher than the untreated sample. This is due to the microwave pretreatment has make the cell walls and cell membranes to lyse and intracellular lipid and protein were released the increased in the proteins and lipids content of the sample [21]. After the microwave irradiation pretreatment, the $\mathrm{O}$ content was decreased. As reported previously, low oxygen content reduce the oxidative degradation and produce high stability of biodiesel [22]

\subsection{FTIR analysis}

The functional group variation of untreated and microwave irradiation pre-treated of chlorella vulgaris was determined using FTIR - ATR (Thermo Fisher Scientific Nicolet iS10). Figure 1compares the FTIR spectra between the untreated and pre-treated microwave irradiation samples.

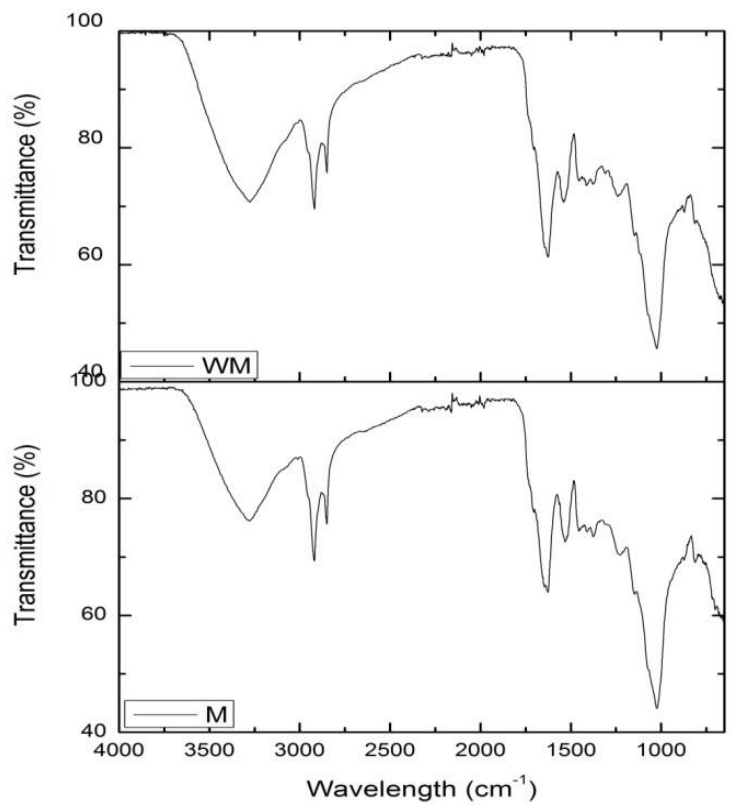

Fig 1: FTIR spectra of (a) untreated (WM) and (b)microwave pre-treated (M) C. vulgaris samples.
Apparently, there was no significant difference between the two spectra indicating that the microwave irradiation did not affect the material compositions of the samples. With reference to Table 3 , the absorption bands from both spectra were consisted of $-\mathrm{CH}$ stretch, N-H stretch of proteins, O-H stretch and $\mathrm{C}=\mathrm{C}$ stretch of fatty acids and $\mathrm{C}=\mathrm{O}$ stretch of ester[23], [24].

Table 3: FTIR results

\begin{tabular}{|c|c|c|c|}
\hline \multicolumn{2}{|c|}{ Wavenumber $\left(\mathrm{cm}^{-1}\right)$} & \multirow[t]{2}{*}{ Functional groups } & \multirow[t]{2}{*}{ References } \\
\hline WM & $\mathrm{M}$ & & \\
\hline 1023.58 & 1023.68 & $\begin{array}{l}\text { C-O stretch associated with } \\
\text { phosphate functional group of } \\
\text { phospholipid }\end{array}$ & [25] \\
\hline 1412.65 & 1374.63 & $\mathrm{C}-\mathrm{H}$ bending of alkanes & {$[26]$} \\
\hline 1539.88 & 1532.28 & $\begin{array}{l}\mathrm{C}-\mathrm{H} \text { and } \mathrm{N}-\mathrm{H} \text { that associated } \\
\text { with proteins }\end{array}$ & [27] \\
\hline 1626.54 & 1626.11 & $\mathrm{C}=\mathrm{C}$ stretch & {$[24]$} \\
\hline 2850.38 & 2850.62 & $\begin{array}{l}\mathrm{C}-\mathrm{H} \text { stretch with symmetrical } \\
\text { vibrate in lipid }\end{array}$ & [24] \\
\hline 2919.76 & 2918.75 & $\begin{array}{l}\mathrm{C}-\mathrm{H} \text { stretch with asymmetrical } \\
\text { vibrate in lipid }\end{array}$ & [24] \\
\hline 32.74 .75 & 3281.34 & $\begin{array}{l}\text { O-H stretch, H-bonded that } \\
\text { present in fatty acids, carbohy- } \\
\text { drates and protein }\end{array}$ & [26] \\
\hline
\end{tabular}

\subsection{Scanning electron microscopy (SEM)}

The surface micro-structure of dried $C$. Vulgaris before and after microwave irradiation pre-treatment was observed under scanning electron microscope (SEM) and is shown in Figure 2. Comparatively, the untreated sample has round-sphere shape cells whereas the microwave pre-treated sample has cells that became agglomerated with the cells shape being distorted due to the disruption of cell walls.

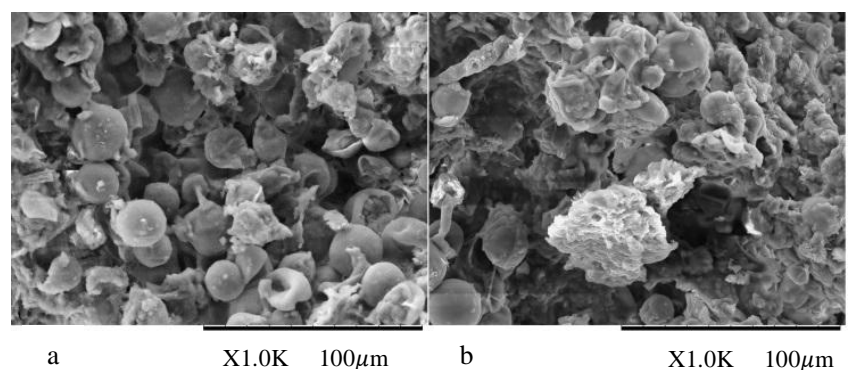

Fig 2: Scanning electron microscope (a) non-treated sample (WM) and (b) microwave treated sample $(\mathrm{M})$.

Similar observation has been reported by Dejoye and co-workers, where the structure of the cell wall was destroyed after the microwave pre-treatment. The cell walls was reported to be torn-off into layers and micro-cracks were created on the cells [15].

\subsection{Statistical analysis}

The relationship of pressure, temperature and $\mathrm{CO}_{2}$ flow rate towards the percentage of extraction yield was investigated. Central composite design in RSM was used to optimize the percentage yield of extraction. In this experiment, 20 runs with varied conditions were conducted.

For the supercritical $\mathrm{CO}_{2}$ extraction of untreated sample, the percentages of extraction yield were varied from $7.97 \%$ to $10.09 \%$ as tabulated in Table 4 . The significance of each coefficient was determined by F-value and p-value obtained from the analysis of variance (ANOVA). The larger the absolute F-value and the smaller the p-value indicate a more significant effect on the respective response variables [28], [29]. The ANOVA result showed the value of 'Prob $>$ F' was less than 0.0500 indicates the model terms to be significant. In this study, $\mathrm{B}^{2}, \mathrm{C}^{2}, \mathrm{AB}$ and $\mathrm{A}^{2} \mathrm{~B}$ were significant model terms. It is suggested that quadratic model is a suitable model with the value of $R^{2}$ was 0.9048 and adj $R^{2}$ was 
0.8454. In this suggested model, the lack of fit F-value was 1.83 implied that the lack of fit was not significant relative to pure error. There is a $20.08 \%$ chance that a model F-value occurred due to noise. From an ANOVA results, the relationship of the factors temperature (A), pressure (B) and $\mathrm{CO}_{2}$ flow rate $(\mathrm{C})$ to the percentage of extraction yield was expressed in equation 3 .

Extraction yield $=9.92+0.043 \mathrm{~A}-0.14 \mathrm{~B}+0.043 \mathrm{C}-$ $0.054 \mathrm{~A}^{2}-0.55 \mathrm{~B}^{2}-0.23 \mathrm{C}^{2}+0.37 \mathrm{AB}-0.071 \mathrm{AC}-0.12 \mathrm{BC}+$ $0.49 \mathrm{~A}^{2} \mathrm{~B}$

Table 4: Actual and predicted result for the percentage of extraction yield of supercritical carbon dioxide extraction without microwave irradiation $\left(\mathrm{SCCO}_{2}-\mathrm{WM}\right)$ and supercritical carbon dioxide extraction with microwave irradiation $\left(\mathrm{SCCO}_{2}-\mathrm{M}\right)$

\begin{tabular}{|c|c|c|c|c|c|c|c|}
\hline & \multirow{2}{*}{$\begin{array}{l}\text { Tempera- } \\
\text { ture }\left({ }^{\circ} \mathrm{C}\right)\end{array}$} & \multirow{2}{*}{$\begin{array}{l}\text { Pres- } \\
\text { sure } \\
(\mathrm{psi})\end{array}$} & \multirow{2}{*}{$\begin{array}{c}\text { Flow } \\
\text { rate } \\
(\mathrm{sL} / \mathrm{mi} \\
\mathrm{n})\end{array}$} & \multicolumn{2}{|c|}{ Actual value } & \multicolumn{2}{|c|}{ Predicted value } \\
\hline & & & & $\begin{array}{l}\mathrm{SCC} \\
\mathrm{O}_{2^{-}} \\
\mathrm{WM}\end{array}$ & $\begin{array}{l}\mathrm{SCC} \\
\mathrm{O}_{2}-\mathrm{M}\end{array}$ & $\begin{array}{l}\mathrm{SCC} \\
\mathrm{O}_{2^{-}} \\
\mathrm{WM}\end{array}$ & $\begin{array}{l}\mathrm{SCC} \\
\mathrm{O}_{2}-\mathrm{M}\end{array}$ \\
\hline 1 & 40 & 3000 & 6 & 8.65 & 8.45 & 8.75 & 8.34 \\
\hline 2 & 70 & 3000 & 6 & 8.41 & 8.66 & 8.33 & 8.43 \\
\hline 3 & 40 & 6000 & 6 & 9.19 & 8.99 & 8.97 & 8.64 \\
\hline 4 & 70 & 6000 & 6 & 9.77 & 9.89 & 10.02 & 9.91 \\
\hline 5 & 40 & 3000 & 10 & 9.56 & 8.61 & 9.23 & 8.40 \\
\hline 6 & 70 & 3000 & 10 & 8.39 & 8.65 & 8.52 & 8.80 \\
\hline 7 & 40 & 6000 & 10 & 8.97 & 8.57 & 8.96 & 8.60 \\
\hline 8 & 70 & 6000 & 10 & 9.91 & 10.28 & 9.72 & 10.19 \\
\hline 9 & 30 & 4500 & 8 & 9.47 & 8.36 & 9.70 & 8.65 \\
\hline 10 & 80 & 4500 & 8 & 10.09 & 10.06 & 9.98 & 10.05 \\
\hline 11 & 55 & 1977 & 8 & 8.43 & 6.42 & 8.49 & 6.56 \\
\hline 12 & 55 & 7023 & 8 & 7.97 & 9.77 & 8.03 & 9.91 \\
\hline 13 & 55 & 4500 & 5 & 9.19 & 8.81 & 9.11 & 9.11 \\
\hline 14 & 55 & 4500 & 11 & 9.06 & 9.42 & 9.26 & 9.40 \\
\hline 15 & 55 & 4500 & 8 & 9.88 & 9.51 & 9.68 & 9.51 \\
\hline 16 & 55 & 4500 & 8 & 9.67 & 9.36 & 9.68 & 9.51 \\
\hline 17 & 55 & 4500 & 8 & 9.75 & 9.86 & 9.68 & 9.51 \\
\hline 18 & 55 & 4500 & 8 & 9.24 & 9.37 & 9.68 & 9.51 \\
\hline 19 & 55 & 4500 & 8 & 9.71 & 9.41 & 9.68 & 9.51 \\
\hline 20 & 55 & 4500 & 8 & 9.88 & 9.61 & 9.68 & 9.51 \\
\hline
\end{tabular}

Another 20 runs were carried out on $\mathrm{SCCO}_{2}$ extraction with microwave irradiation pre-treated samples. ANOVA was applied after the experiment was carried out and the model presented was significant with F-value of 17.86 and p-value was less than 0.0500. Therefore, it can be concluded $\mathrm{A}, \mathrm{B}, \mathrm{B}^{2}, \mathrm{AB}$ and $\mathrm{A}^{2} \mathrm{~B}$ were significant model terms. The $\mathrm{R}^{2}$ obtained was 0.952 which indicates that the experimental values had minimum deviation from the predicted values. This also showed that the model has good fitting degree with $95.2 \%$ of the changes in response could be explained and the error was fairly small. In this quadratic model, the lack of fit F-value is 3.28 was not significant relative to the pure error. There was $11.25 \%$ chance that the lack of fit Fvalue occured due to noise. Non - significant of lack of fit is required to ensure that the model was well fitted. "Adeq precision" is a measure of signal to noise ratio. In this model the ratio was 17.975. It was reported previously that the ratio obtained that is higher than 4 is good for the significant model [30]. A regression analysis was conducted and an equation was expressed using coded values as in equation 4 .

Yield $=9.51+0.42 \mathrm{~A}+1.0 \mathrm{~B}+0.084 \mathrm{C}-0.057 \mathrm{~A}^{2}-0.45 \mathrm{~B}^{2}-$ $0.091 \mathrm{C}^{2}+0.30 \mathrm{AB}+0.080 \mathrm{AC}-0.022 \mathrm{BC}-0.58 \mathrm{~A}^{2} \mathrm{~B}$

Table 5: ANOVA for response surface quadratic model for $\mathrm{SCCO}_{2}$ extraction without microwave irradiation pre-treatment samples

\begin{tabular}{lcccccc}
\hline Source & $\begin{array}{c}\text { Sum of } \\
\text { square }\end{array}$ & DF & $\begin{array}{c}\text { Mean } \\
\text { square }\end{array}$ & $\begin{array}{c}\text { F- } \\
\text { value }\end{array}$ & Prob>F & \\
\hline Model & 6.54 & 10 & 0.65 & 8.55 & 0.0017 & Significant \\
A & 0.09 & 1 & 0.09 & 0.38 & 0.2883 & \\
B & 0.11 & 1 & 0.11 & 1.38 & 0.2695 & \\
C & 0.02 & 1 & 0.02 & 0.59 & 0.5768 & \\
$\mathrm{~A}^{2}$ & 0.04 & 1 & 0.04 & 47.69 & 0.4630 & \\
\hline
\end{tabular}

\begin{tabular}{lcccccc}
\hline $\mathrm{B}^{2}$ & 3.64 & 1 & 3.64 & 5.83 & $<0.0001$ & Significant \\
$\mathrm{C}^{2}$ & 0.45 & 1 & 0.45 & 14.05 & 0.0390 & Significant \\
$\mathrm{AB}$ & 1.07 & 1 & 1.07 & 14.05 & 0.0046 & Significant \\
$\mathrm{AC}$ & 0.04 & 1 & 0.04 & 0.53 & 0.4845 & \\
$\mathrm{BC}$ & 0.12 & 1 & 0.12 & 1.54 & 0.2461 & \\
$\mathrm{~A}^{2} \mathrm{~B}$ & 0.80 & 1 & 0.80 & 10.44 & 0.0103 & Significant \\
Residual & 0.69 & 9 & 0.07 & & & \\
Lack of & 0.41 & 4 & 0.10 & 1.83 & 0.2068 & Not sig- \\
fit & & & & & & nificant \\
$\begin{array}{l}\text { Pure } \\
\text { error }\end{array}$ & 0.28 & 5 & 0.056 & & & \\
Cor & 7.22 & 19 & & & & \\
total & & & & & & \\
\hline
\end{tabular}

Table 6: ANOVA for response surface quadratic model for $\mathrm{SCCO}_{2}$ extraction with microwave irradiation pre-treatment samples

\begin{tabular}{|c|c|c|c|c|c|c|}
\hline Source & $\begin{array}{l}\text { Sum of } \\
\text { square }\end{array}$ & $\mathrm{DF}$ & $\begin{array}{l}\text { Mean } \\
\text { square }\end{array}$ & $\begin{array}{c}\text { F- } \\
\text { value }\end{array}$ & Prob $>F$ & \\
\hline Model & 13.23 & 10 & 1.32 & 17.86 & $<0.0001$ & Significant \\
\hline A & 2.39 & 1 & 2.39 & 32.34 & 0.0003 & Significant \\
\hline B & 5.61 & 1 & 5.61 & 75.78 & $<0.0001$ & Significant \\
\hline $\mathrm{C}$ & 0.09 & 1 & 0.09 & 1.30 & 0.2839 & \\
\hline $\mathrm{A}^{2}$ & 0.04 & 1 & 0.04 & 0.63 & 0.4467 & \\
\hline $\mathrm{B}^{2}$ & 2.93 & 1 & 2.93 & 39.63 & 0.0001 & Significant \\
\hline $\mathrm{C}^{2}$ & 0.12 & 1 & 0.12 & 1.60 & 0.2379 & \\
\hline $\mathrm{AB}$ & 0.70 & 1 & 0.70 & 9.40 & 0.0134 & Significant \\
\hline $\mathrm{AC}$ & 0.05 & 1 & 0.051 & 0.69 & 0.4272 & \\
\hline $\mathrm{BC}$ & $\underset{-3}{4.05 \times 10}$ & 1 & $\underset{3}{4.05 \times 10^{-}}$ & 0.05 & 0.8203 & \\
\hline$A^{2} B$ & 1.10 & 1 & 1.10 & 14.85 & 0.0039 & Significant \\
\hline Residual & 0.67 & 9 & 0.07 & & & \\
\hline $\begin{array}{l}\text { Lack of } \\
\text { fit }\end{array}$ & 0.48 & 4 & 0.12 & 3.28 & 0.1125 & $\begin{array}{l}\text { Not sig- } \\
\text { nificant }\end{array}$ \\
\hline $\begin{array}{l}\text { Pure } \\
\text { error }\end{array}$ & 0.18 & 5 & 0.04 & & & \\
\hline $\begin{array}{l}\text { Cor } \\
\text { total }\end{array}$ & 13.90 & 19 & & & & \\
\hline
\end{tabular}

\subsection{Effect of pressure, temperature and flow rate on $\mathrm{SCCO}_{2}$}

The results of extraction yield of $C$. vulgaris at various temperature, pressure and $\mathrm{CO}_{2}$ flow rate were tabulated in Table 4 for $\mathrm{SCCO}_{2}$ - untreated (WM) and $\mathrm{SCCO}_{2}$ - microwave irradiation pretreatment (M). Analysis of variance was carried out using data obtained and the three-dimensional response surfaces were plotted as a function of the interaction of any two variables by holding the other one at central point. The extraction temperature and pressure were found to significantly affecting the percentage yield of extraction while the flow rate has no significant effect to the percentage of extraction yield.

The percentage of extraction yield increased gradually when the extraction pressure was increased at constant $\mathrm{CO}_{2}$ flow rate. Figure $3 \mathrm{a}$ and $\mathrm{b}$ showed the response surface plot of pressure and temperature to the pencentage of extraction yield at constant $\mathrm{CO}_{2}$ flow rate of $8 \mathrm{sL} / \mathrm{min}$. Pressure gave a positive linear effect on percentage of extraction yield for supercritical fluid extraction with and without microwave pre-treatment. This might be due to the improvement of oil solubility resulted from the increased of $\mathrm{CO}_{2}$ density [29]. The maximum extraction yield was achieved at pressure $4500 \mathrm{psi}$ at temperature $80^{\circ} \mathrm{C}$ with $10.09 \%$. However, at $7023 \mathrm{psi}$, the percentage of extraction yield decreased to $7.97 \%$. Similar observation for $\mathrm{SCCO}_{2}$ with microwave irradiation pretreatment $\left(\mathrm{SCCO}_{2}-\mathrm{M}\right)$ was found whereby at 7023 psi the percentage of extraction yield was $9.77 \%$. This trend occurred due to the maximum solubility of the solvent achieved regardless of the high pressure applied [31]. At high pressure, the solubility of the lipid increases due to the increase in density of $\mathrm{CO}_{2}$. As the density increases, the distance between molecules decreases and the interaction between lipid and $\mathrm{CO}_{2}$ increases, leading to greater oil solubility in $\mathrm{CO}_{2}[32]$. 

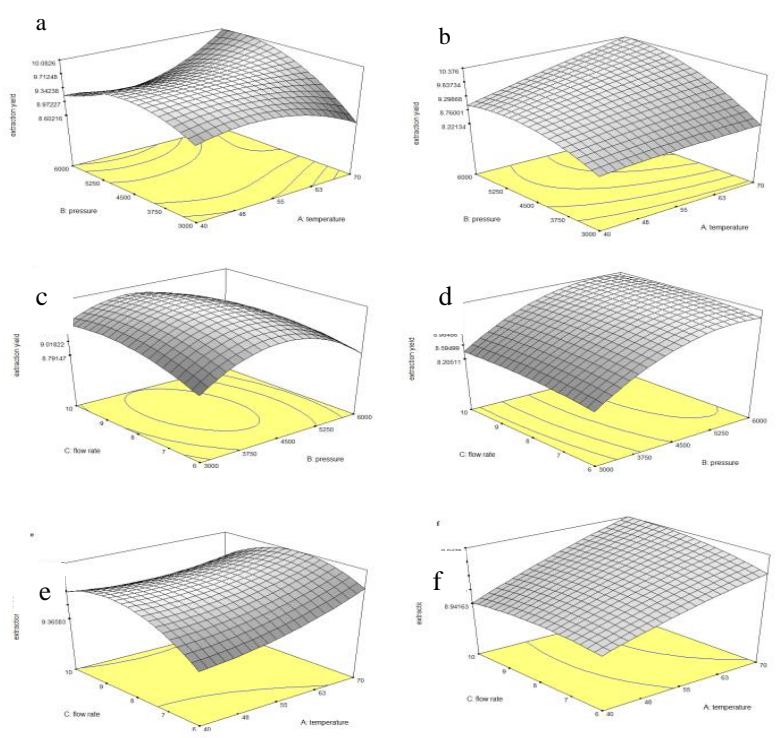

Fig 3: Surface plot of extraction yield (a) $\mathrm{SCCO}_{2}-\mathrm{WM}$, (b) $\mathrm{SCCO}_{2}-\mathrm{M}$ effect of pressure and temperature at constant flowrate; (c) $\mathrm{SCCO}_{2}-\mathrm{WM}$, (d) $\mathrm{SCCO}_{2}-\mathrm{M}$ - effect of pressure and $\mathrm{CO}_{2}$ flow rate at constant temperature; (e) $\mathrm{SCCO}_{2}-\mathrm{WM}$, (f) $\mathrm{SCCO}_{2}-\mathrm{M}$ - effect of temperature and $\mathrm{CO}_{2}$ flow rate at constant pressure

Meanwhile, the temperature showed negative linear effect to the percentage of extraction yield. However, when there is an interaction with the pressure, it showed positive effect on the percentage of extraction yield. When the temperature and pressure increased, the percentage of extraction yield increased. For the $\mathrm{SCCO}_{2}-\mathrm{WM}$, at the pressure of $3000 \mathrm{psi}$, and in higher temperature $\left(70^{\circ} \mathrm{C}\right)$, the percentage of extraction yield obtained was $8.39 \%$. While, at the lower temperature $\left(40^{\circ} \mathrm{C}\right)$, the percentage extraction yield obtained was $9.56 \%$. This occurred due to the the reduction of the $\mathrm{CO}_{2}$ solubility at the high temperatures. However, at higher pressure, the percentage of extraction yield increased with the increase of temperature. This crossover phenomenon were also reported in previous works for other supercritical fluid extraction [29], [33]. Figure $3 \mathrm{c}$ and $\mathrm{d}$ shows the effect of $\mathrm{CO}_{2}$ flow rate and pressure on the percentage of extraction yield for $\mathrm{SCCO}_{2}-\mathrm{WM}$ and $\mathrm{SCCO}_{2}-\mathrm{M}$. $\mathrm{CO}_{2}$ flow rate and pressure showed negative linear effect towards percentage of extraction yield. This was similar to the effect of $\mathrm{CO}_{2}$ flow rate and temperature. It can be concluded that, the $\mathrm{CO}_{2}$ flow rate has no significant effect to the percentage of extraction yield in comparison to pressure and temperature.

\subsection{Optimization of extraction conditions}

Multiple response optimizations could be generated from a contour plot of the variables. The $\mathrm{SCCO}_{2}$ extraction with and without microwave irradiation pre-treatment condition would be considered optimum if the yield of lipids reached the maximum values. The model equation had predicted the optimum condition for the $\mathrm{SCCO}_{2}-\mathrm{WM}$ was at $70^{\circ} \mathrm{C}, 5479 \mathrm{psi}$ and $8 \mathrm{sL} / \mathrm{min}$ while optimum condition for $\mathrm{SCCO}_{2}-\mathrm{M}$ was at $65^{\circ} \mathrm{C}, 5857 \mathrm{psi}$ and $9 \mathrm{sL} / \mathrm{min}$.

\subsection{Fatty acid methyl ester (FAME) composition}

The composition of FAMEs in extracted lipids of $\mathrm{SCCO}_{2}-\mathrm{WM}$ and $\mathrm{SCCO}_{2}$-M were determined using GC-MS after transesterification were carried out. Oleic acid was the highest constituent in both samples, while the main components in SCCO2-WM were linoleic acid, palmitic acid and oleic. On the other hand, in $\mathrm{SCCO}_{2}-\mathrm{M}$, palmitoleic acid, palmitic acid and oleic acid were more abundant in comparison to the other FAMEs. Previous study had reported palmitic acid, stearic acid, oleic acid and linoleic acid were recognised as the most common fatty acids present in the biodiesel [34]. As presented in Table 7, the contents of saturated fatty acids (SFA) and monounsaturated fatty acids (MUFA) in $\mathrm{SCCO}_{2}-\mathrm{M}$ extracted lipids were higher in comparison to $\mathrm{SCCO}_{2-}$ WM extracted lipids. The contents of SFA and MUFA in $\mathrm{SCCO}_{2-}^{-}$ $\mathrm{M}$ extracted lipids were $40.25 \%$ and $51.84 \%$ respectively. While in the $\mathrm{SCCO}_{2}-\mathrm{WM}$, the content of SFA and MUFA was $38.21 \%$ and $37.87 \%$, respectively. However, the composition of polyunsaturated fatty acid (PUFA) in $\mathrm{SCCO}_{2}$-M extracted lipids was lower $(7.90 \%)$ than $\mathrm{SCCO}_{2}$-WM $(23.48 \%)$. This observation might be due to the electromagnetic effect that is produced by the microwave irradiation that ruptured the unstable bonds in a carbon chain and changed its structure [35]. Furthermore, heat that is produced from the electromagnetic effect from microwave irradiation had caused the cell to lyse [36]. The heat transfer in microwave irradiation usually takes place by dipolar polarisation, ionic conduction and interfacial polarisation mechanism to enhance the localised and rapid heating of reaction materials [37].

Table 7: Compositions of Fatty acid methyl ester (FAME) in supercritical carbon dioxide extraction with and without microwave irradiation pretreatment.

\begin{tabular}{llcc}
\hline & Fatty acid & \multicolumn{2}{c}{ Relative proportion area (\%) } \\
& methyl ester & $\mathrm{SCCO}_{2}$-WM & $\mathrm{SCCO}_{2}$-M \\
C 14:0 & Mristic acid & 2.20 & 2.42 \\
C16:0 & Palmitic acid & 24.51 & 24.40 \\
C16:1 & Palmitoleic acid & N.A & 14.08 \\
C18:0 & Stearic acid & 5.93 & 6.02 \\
C18:1 & Oleic acid & 37.09 & 36.58 \\
C18:2 & Linoleic acid & 17.62 & N.A \\
C18:3 & $\alpha-$-linolenic acid & N.A & 1.86 \\
C20:0 & Arachidic acid & 1.96 & 2.52 \\
C20:4 & Arachidonic acid & 2.23 & 1.72 \\
C 22:0 & Behenic acid & 1.22 & 1.32 \\
$\sum$ SFA* & & 38.21 & 40.25 \\
$\sum$ MUFA & & & \\
$\sum$ PUFA & & 37.87 & 51.84 \\
\hline
\end{tabular}

*SFA $=$ saturated fatty acid

*MUFA = monounsaturated fatty acid

*PUFA= polyunsaturated fatty acid

Interestingly, the microwave pre-treatment sample produced lower PUFA content in comparison to sample without microwave pretreatment. In fact, it is desirable to have low PUFA content for biodiesel production because high PUFA bio-oils can cause poor volatility, low oxidation stability and tendency for gum formation as observed in some oilseed-derived biodiesel [38].

\section{Conclusion}

Optimization of supercritical carbon dioxide extraction conditions (pressure, temperature and $\mathrm{CO}_{2}$ flow rate) of bio-oil from microalgae was successfully achieved using response surface methodology (RSM) with central composite design. Both temperature and pressure showed significant effect towards the percentage of extraction yield. $\mathrm{CO}_{2}$ flow rate however, showed no significant effect to the percentage of extraction yield. In addition, fatty acids such as $\alpha$-linolenic acid and palmitoleic acid were present in the microwave irradiation pre-treated bio-oil sample. The fatty acid compositions of bio-oil extracted from $\mathrm{SCCO}_{2}$ with microwave irradiation pre-treatment showed higher content of saturated and monounsaturated fatty acids in comparison to bio-oil from untreated sample and are favourable for bio-diesel production.

\section{Acknowledgement}

The authors acknowledged Universiti Teknologi MARA for their support. Thanks to Ministry of Higher Education for funding this 
research and Faculty of Applied Sciences UiTM Shah Alam for their facilities.

\section{References}

[1] a. L. Ahmad, N. H. M. Yasin, C. J. C. Derek, and J. K. Lim "Microalgae as a sustainable energy source for biodiesel production: A review," Renew. Sustain. Energy Rev., vol. 15, no. 1, pp. 584593, Jan. 2011

[2] A. Demirbas and M. Fatih Demirbas, "Importance of algae oil as a source of biodiesel," Energy Convers. Manag., vol. 52, no. 1, pp 163-170, Jan. 2011.

[3] J. R. McMillan, I. A. Watson, M. Ali, and W. Jaafar, "Evaluation and comparison of algal cell disruption methods: Microwave, waterbath, blender, ultrasonic and laser treatment," Appl. Energy, vol. 103, pp. 128-134, Mar. 2013.

[4] J.-Y. Lee, C. Yoo, S.-Y. Jun, C.-Y. Ahn, and H.-M. Oh, "Comparison of several methods for effective lipid extraction from microalgae.," Bioresour. Technol., vol. 101 Suppl, no. 1, pp. S75-7, Jan. 2010.

[5] A. Bahadar, M. B. Khan, M. a Asim, and K. Jalwana, Chapter 21 Supercritical Fluid Extraction of Microalgae (Chlorella vulagaris) Biomass. Elsevier, 2015.

[6] C.-H. Cheng, T.-B. Du, H.-C. Pi, S.-M. Jang, Y.-H. Lin, and H.-T Lee, "Comparative study of lipid extraction from microalgae by organic solvent and supercritical CO2.," Bioresour. Technol., vol. 102, no. 21, pp. 10151-3, Nov. 2011.

[7] S. Đurđević, S. Milovanović, K. Šavikin, M. Ristić, N. Menković, D. Pljevljakušić, S. Petrović, and A. Bogdanović, "Improvement of supercritical CO 2 and $\mathrm{n}$-hexane extraction of wild growing pomegranate seed oil by microwave pretreatment," Ind. Crops Prod., vol. 104, no. December 2016, pp. 21-27, 2017.

[8] A. T. C. Y. GE, Y. NI, H. YAN, Y. CHEN, "Optimization of the Supercritical Fluid Extraction of Natural Vitamin E from Wheat Germ Using Response Surface Methodology," J. Food Sci., vol. 67, no. 1, 2002.

[9] S. R. R. Comim, K. Madella, J. V. Oliveira, and S. R. S. Ferreira, "Supercritical fluid extraction from dried banana peel (Musa spp., genomic group $\mathrm{AAB}$ ): Extraction yield, mathematical modeling, economical analysis and phase equilibria," J. Supercrit. Fluids, vol. 54, no. 1 , pp. $30-37,2010$

[10] M. J. H. Akanda, M. Z. I. Sarker, N. Norulaini, S. Ferdosh, M. M. Rahman, and A. K. M. Omar, "Optimization of supercritical carbon dioxide extraction parameters of cocoa butter analogy fat from mango seed kernel oil using response surface methodology," $J$. Food Sci. Technol., vol. 52, no. 1, pp. 319-326, 2015.

[11] C. Safi, B. Zebib, O. Merah, P.-Y. Pontalier, and C. Vaca-Garcia, "Morphology, composition, production, processing and applications of Chlorella vulgaris: A review," Renew. Sustain. Energy Rev., vol. 35 , pp. 265-278, 2014

[12] J. H. Waterborg and H. R. Matthews, "The lowry method for protein quantitation.," Methods Mol. Biol., vol. 1, pp. 1-3, 1984.

[13] S. S. Nielsen, "Food Analysis Laboratory Manual," Evaluation, pp. 9-16, 2010.

[14] Y. Hu, M. Gong, C. (Charles) Xu, and A. Bassi, "Investigation of an alternative cell disruption approach for improving hydrothermal liquefaction of microalgae," Fuel, vol. 197, pp. 138-144, 2017.

[15] C. Dejoye, M. A. Vian, G. Lumia, C. Bouscarle, F. Charton, and F. Chemat, "Combined extraction processes of lipid from Chlorella vulgaris microalgae: Microwave prior to supercritical carbon dioxide extraction," Int. J. Mol. Sci., vol. 12, no. 12, pp. 9332-9341, Dec. 2011

[16] C. Crampon, A. Mouahid, S.-A. A. Toudji, O. Lépine, and E. Badens, "Influence of pretreatment on supercritical CO2 extraction from Nannochloropsis oculata," J. Supercrit. Fluids, vol. 79, pp. 337-344, Jul. 2013.

[17] K. M. Isa, S. Daud, N. Hamidin, K. Ismail, S. A. Saad, and F. H. Kasim, "Thermogravimetric analysis and the optimisation of bio-oil yield from fixed-bed pyrolysis of rice husk using response surface methodology (RSM)," Ind. Crops Prod., vol. 33, no. 2, pp. 481487, 2011.

[18] M. 'Azim Jamaluddin, K. Ismail, M. A. Mohd Ishak, Z. Ab Ghani, M. F. Abdullah, M. T. U. Safian, S. S. Idris, S. Tahiruddin, M. F. Mohammed Yunus, and N. I. N. Mohd Hakimi, "Microwaveassisted pyrolysis of palm kernel shell: Optimization using response surface methodology (RSM)," Renew. Energy, vol. 55, pp. 357-365, 2013.
[19] N. Aslan, "Application of response surface methodology and central composite rotatable design for modeling and optimization of a multi-gravity separator for chromite concentration," Powder Technol., vol. 185, no. 1, pp. 80-86, 2008.

[20] H.-Y. Shin, J.-H. Ryu, S.-Y. Bae, C. Crofcheck, and M. Crocker, "Lipid extraction from Scenedesmus sp. microalgae for biodiesel production using hot compressed hexane," 2014.

[21] Z. Hu, X. Ma, and E. Jiang, "The effect of microwave pretreatment on chemical looping gasification of microalgae for syngas production," Energy Convers. Manag., vol. 143, pp. 513-521, 2017.

[22] P. Nautiyal, K. a. Subramanian, and M. G. Dastidar, "Production and characterization of biodiesel from algae," Fuel Process. Technol., vol. 120, pp. 79-88, Apr. 2014.

[23] D. Surendhiran and M. Vijay, "Effect of Various Pretreatment for Extracting Intracellular Lipid from Nannochloropsis oculata under Nitrogen Replete and Depleted Conditions," ISRN Chem. Eng., vol. 2014, pp. 1-9, 2014.

[24] R. S. Pohndorf, Á. S. Camara, A. P. Q. Larrosa, C. P. Pinheiro, M. M. Strieder, and L. A. A. Pinto, "Production of lipids from microalgae Spirulina sp.: Influence of drying, cell disruption and extraction methods," Biomass and Bioenergy, vol. 93, pp. 25-32, 2016.

[25] S. Dharma, H. H. Masjuki, H. Chyuan, A. H. Sebayang, A. S Silitonga, F. Kusumo, and T. M. I. Mahlia, "Optimization of biodiesel production process for mixed Jatropha curcas - Ceiba pentandra biodiesel using response surface methodology," Energy Convers. Manag., vol. 115, pp. 178-190, 2016.

[26] A. Rai, B. Mohanty, and R. Bhargava, "Modeling and response surface analysis of supercritical extraction of watermelon seed oil using carbon dioxide," Sep. Purif. Technol., vol. 141, pp. 354-365, 2015.

[27] N. Söyler, J. L. Goldfarb, S. Ceylan, and M. T. Saçan, "Renewable fuels from pyrolysis of Dunaliella tertiolecta: An alternative approach to biochemical conversions of microalgae," Energy, vol. 120, pp. 907-914, 2017.

[28] G. Sodeifian, N. Saadati Ardestani, S. A. Sajadian, and S. Ghorbandoost, "Application of supercritical carbon dioxide to extract essential oil from Cleome coluteoides Boiss: Experimental, response surface and grey wolf optimization methodology," $J$. Supercrit. Fluids, vol. 114, pp. 55-63, 2016.

[29] X. Xu, Y. Gao, G. Liu, Q. Wang, and J. Zhao, "Optimization of supercritical carbon dioxide extraction of sea buckthorn (Hippophae thamnoides L.) oil using response surface methodology," LWT - Food Sci. Technol., vol. 41, no. 7, pp. 1223 1231, 2008.

[30] X. Wang, H. Zou, and L. Liu, "Optimizing synthesis parameters of short carbon fiber reinforced polysulfonamide composites by using response surface methodology," Polymer Testing, 2017.

[31] A. Y. Ani, M. Azlan, M. Ishak, and K. Ismail, "Production of Biodiesel via In-Situ Supercritical Methanol Transesterification," Biodiesel-Feed. Process. Technol., pp. 229-246, 2011.

[32] Z. Hou, Y. Zheng, Y. Gao, X. Liu, F. Yuan, and G. Liu, "Optimization of supercritical carbon dioxide removal of lipid and cholesterol from goat placenta using response surface methodology," Food Bioprod. Process., vol. 88, no. 2-3, pp. 298-304, 2010.

[33] E. Yildiz-Ozturk and O. Yesil-Celiktas, "Supercritical CO2 extraction of hydrocarbons from Botryococcus braunii as a promising bioresource," J. Supercrit. Fluids, vol. 130, no. February, pp. 261-266, 2017

[34] N. A. Nik Norulaini, W. B. Setianto, I. S. M. Zaidul, A. H. Nawi, C. Y. M. Azizi, and A. K. M. Omar, "Effects of supercritical carbon dioxide extraction parameters on virgin coconut oil yield and medium-chain triglyceride content," Food Chem., vol. 116, no. 1, pp. 193-197, 2009

[35] A. Piasecka, I. Krzemińska, and J. Tys, "Physical Methods of Microalgal Biomass Pretreatment," Int. Agrophysics, vol. 28, no. 3, pp. 341-348, 2014

[36] M. Ali and I. A. Watson, "Microwave treatment of wetalgal paste for enhanced solvent extraction of lipids for biodiesel production,' Renew. Energy, vol. 76, pp. 470-477, 2015.

[37] A. K. Sharma, P. K. Sahoo, S. Singhal, and G. Joshi, "Exploration of upstream and downstream process for microwave assisted sustainable biodiesel production from microalgae Chlorella vulgaris," Bioresour. Technol., vol. 216, pp. 793-800, 2016.

[38] R. Halim, M. K. Danquah, and P. a Webley, "Extraction of oil from microalgae for biodiesel production: A review.," Biotechnol. Adv., vol. 30, no. 3, pp. 709-32, 2012. 